\title{
Pathogenic Variation in the Pearl Millet Blast Pathogen Magnaporthe grisea and Identification of Resistance to Diverse Pathotypes
}

Rajan Sharma, H. D. Upadhyaya, S. V. Manjunatha, K. N. Rai, S. K. Gupta, and R. P. Thakur, International Crops Research Institute for the Semi-Arid Tropics, Patancheru 502324, Andhra Pradesh, India

\begin{abstract}
Sharma, R., Upadhyaya, H. D., Manjunatha, S. V., Rai, K. N., Gupta, S. K., and Thakur, R. P. 2013. Pathogenic variation in the pearl millet blast pathogen Magnaporthe grisea and identification of resistance to diverse pathotypes. Plant Dis. 97:189-195.

Blast, also known as leaf spot, caused by Pyricularia grisea (teleomorph: Magnaporthe grisea), has emerged as a serious disease affecting both forage and grain production in pearl millet in India. Pathogenic variation was studied in a greenhouse using $25 \mathrm{M}$. grisea isolates collected from four major pearl-millet-growing states in India (Rajasthan, Haryana, Maharashtra, and Uttar Pradesh) on 10 pearl millet genotypes (ICMB 02444, ICMB 02777, ICMB 06444, ICMB 93333, ICMB 96666, ICMB 97222, ICMB 99444, 863B, ICMR 06222, and ICMB 95444). Differential reactions to the test isolates were recorded on ICMB 02444, ICMB 93333, ICMB 97222, 863B, and ICMR 06222. The 25 isolates were grouped into five different pathotypes based on their reaction types (virulent $=$ score $\geq 4$ and avirulent $=$ score $\leq 3$ on a 1-to-9 scale). For the identification of resistance sources, a pearl millet

conditions against five M. grisea isolates (Pg118, Pg119, Pg56, Pg53, and $\mathrm{Pg} 45$ ) representing the five pathotypes. Of 238 accessions, 32 were found to be resistant to at least one pathotype. Resistance to multiple pathotypes (two or more) was recorded in several accessions, while three accessions (IP 7846, IP 11036, and IP 21187) exhibited resistance to four of the five pathotypes. Four early-flowering ( $\leq 50$ days) blast-resistant mini-core accessions (IP 7846, IP 4291, IP 15256, and IP 22449) and four accessions (IP 5964, IP 11010, IP 13636, and IP 20577 ) having high scores $(\geq 7)$ for grain and green fodder yield potential and overall plant aspect were found to be promising for utilization in pearl millet improvement programs. Identification of five pathotypes of $M$. grisea and sources of resistance to these pathotypes will provide a foundation for breeding for blast resistance in pearl millet in India.
\end{abstract} mini-core comprising 238 accessions was evaluated under greenhouse
Pearl millet (Pennisetum glaucum (L.) R. Br.) is a C4 cereal grown mostly in the arid and semiarid regions of Africa and Asia on 26 million ha (16) and is the sixth-ranked cereal after wheat (Triticum aestivum L.), maize (Zea mays L.), rice (Oryza sativa L.), barley (Hordeum vulgare L.), and sorghum (Sorghum bicolor (L.) Moench). It is primarily cultivated for grain but is also a valuable source of fodder (both stover and green forage). In nontraditional areas, such as the southern United States, Brazil, Australia, and Korea, it is grown for forage and silage production for dairy.

During the past three decades, single-cross $F_{1}$ hybrids based on cytoplasmic-nuclear male-sterility systems have contributed significantly to increase pearl millet productivity in India because the single-cross hybrids of pearl millet have 25 to $30 \%$ grain yield advantage over open-pollinated varieties (17). However, stresses such as drought and disease pose a continuous threat to the successful realization of high productivity in pearl millet. Among several diseases that affect pearl millet, downy mildew caused by Sclerospora graminicola (Sacc.) J. Schröt. has been a major problem of pearl millet hybrids. During recent years, blast, also known as leaf spot, caused by Pyricularia grisea Sacc. (teleomorph: Magnaporthe grisea (T.T. Herbert) M.E. Barr), has emerged as another serious disease in major pearl-millet-growing areas in India. This disease causes substantial yield losses of grain (23) and forage (30). Symptoms of the disease appear as gray, water-soaked foliar lesions that enlarge and become necrotic, resulting in extensive chlorosis and premature drying of young leaves (29). This disease becomes more severe during humid weather conditions, especially with dense plant stands. Leaf blast on pearl millet has been found to be negatively correlated with green-plot yield, dry-matter yield,

Corresponding author: R. Sharma, E-mail: r.sharma@cgiar.org

Accepted for publication 23 August 2012.

http://dx.doi.org/10.1094/PDIS-05-12-0481-RE

(C) 2013 The American Phytopathological Society and digestive dry matter thus affecting the productivity and quality of the crop (30).

In India, the disease was first reported from Kanpur, Uttar Pradesh (12). Although blast was considered a minor disease of pearl millet in India, the disease incidence has increased alarmingly during recent years $(1,11)$. The blast pathogen infects several cereal crops, including rice, wheat, pearl millet, finger millet, and foxtail millet, and several grasses. The pathogen is highly variable but highly specialized in its host range. Thus, $M$. grisea strains from rice or any other hosts do not infect pearl millet and vice versa. The rice-blast pathosystem has been extensively studied. In disease-conducive environments, the lifespan of many diseaseresistant rice cultivars has been known to be ephemeral (19). Most of the resistance genes in rice break down in a few years because of their race specificity and the rapid change in pathogenicity of the blast fungus (20). Pathogenic variation in $M$. grisea populations adapted to rice, finger millet, foxtail millet, wheat, and several weed hosts has been reported $(13,15,21)$. Various potential mechanisms, including sexual recombination, heterokaryosis, parasexual recombination, and aneuoploidy, have been proposed to explain frequent race changes in $M$. grisea (10). This implies that pathogenic variability might exist in the pearl millet-infecting strains of $M$. grisea. Therefore, for the management of this disease through host plant resistance, it is important to study pathogenic variation in pearl-millet-infecting populations of $M$. grisea and identify resistance sources to virulent pathotypes.

Plant genetic resources conserved in gene banks can be tapped for the identification of resistance sources to various biotic and abiotic stresses (26). The gene bank at the International Crops Research Institute for the Semi-Arid Tropics (ICRISAT), Patancheru, India has assembled 21,594 pearl millet accessions (the term "accession" is used to describe a distinct type or variety of plant collected at a specific location and time) originating from 50 countries, including 750 accessions of 24 wild species of genus Pennisetum exhibiting variation for different traits (27). However, because of the large size of the collection, precise evaluation is a complicated and expensive process that can impede effective 
utilization of the germplasm. Therefore, the collection needs to be reduced to a meaningful and manageable level for evaluation for the traits of economic importance. To solve these problems, Frankel (3) proposed the establishment of a core collection $(10 \%$ of entire collection) that could be selected from the existing collection of crop species resources in a gene bank. In pearl millet, Bhattacharjee et al. (2) developed a core collection comprising 1,600 accessions. This core collection was augmented with 501 accessions representing 4,717 new accessions and exclusion of 7 accessions (5 duplicates and 2 male sterile lines), resulting in a revised core collection of 2,094 accessions (24). However, the size of the core collection $(2,094$ accessions) was still too large for replicated multiple evaluations to identify sources of traits of economic importance. To overcome this, the concept of a mini-core collection, comprising $10 \%$ of the core or $1 \%$ of the entire collection, which still represents most of the useful variation in a crop species, was utilized (25). Thus, a mini-core collection of pearl millet comprising 238 accessions developed at ICRISAT (28) was evaluated to identify sources of resistance to $M$. grisea. The objectives of this study were to study pathogenic variability in pearlmillet-infecting populations of $M$. grisea in India, and identify sources of resistance in the pearl millet mini-core collection to diverse pathotypes.

\section{Materials and Methods}

Pathogenic variability. Isolate collection and maintenance. Farmers' fields were surveyed in the four major pearl-milletgrowing states in India (Rajasthan, Haryana, Maharashtra, and Uttar Pradesh) during August to September 2009 and 2010 for the prevalence of pearl millet blast. Pearl millet fields were randomly selected along main roads and, occasionally, on feeder roads, and blast severity was visually assessed as percent leaf area of plants showing typical blast symptoms. In total, $25 \mathrm{M}$. grisea isolates were collected from the blast-infected fields (Table 1). Isolations of $M$. grisea were made from the blast-infected tissue on oatmeal agar (rolled oats, $50 \mathrm{~g}$; agar, $15 \mathrm{~g}$; and distilled water, 1 liter) at ICRISAT, Patancheru, Andhra Pradesh, India. After incubating the cultures at $25 \pm 1{ }^{\circ} \mathrm{C}$ for 15 days, a dilute spore suspension $\left(3 \times 10^{3}\right.$ spores $\mathrm{ml}^{-1}$ ) was prepared in distilled water and plated onto $4 \%$ water agar in petri plates. After 10 to $12 \mathrm{~h}$ of incubation, single germinating conidia were selected under a microscope and transferred to test tubes containing oatmeal agar for further studies.

Host differentials. Differential hosts are sets of plant cultivars used to distinguish pathotypes (races) by their qualitative differences in their reactions (susceptible and resistant) to different isolates of the pathogen. Ten pearl millet genotypes (ICMB 02444, ICMB 02777, ICMB 06444, ICMB 93333, ICMB 96666, ICMB 97222, ICMB 99444, 863B, ICMR 06222, and ICMB 95444) that had shown differential reactions in the pearl millet blast variability nursery evaluated at several locations in India during 2010 were selected as host differentials (1).

Inoculum preparation and inoculation of host differentials. Inoculum of each isolate was multiplied on oatmeal agar plates by incubating the inoculated plates at $25^{\circ} \mathrm{C}$ with $12 \mathrm{~h}$ of darkness for 7 to 10 days. Spores were harvested by flooding the plates with sterilized distilled water and scraping the growth by a spatula. The spore suspension was adjusted to the desired concentration $\left(1 \times 10^{5}\right.$ spore $\mathrm{ml}^{-1}$ ) with the help of a hemocytometer, and a drop of a surfactant (Tween 20) was added to ensure the uniform dispersal of spores.

Seed of host differentials was planted in $15-\mathrm{cm}$-diameter pots (10 seeds/pot) filled with a sterilized soil/sand/FYM (farm yard manure) mix (2:1:1 by volume) and placed in a greenhouse bay maintained at $32 \pm 1{ }^{\circ} \mathrm{C}$. Pot-grown seedlings (12 days old) were spray inoculated with an aqueous conidial suspension of each isolate, covered with polyethylene bags, and incubated at $25^{\circ} \mathrm{C}$ for $24 \mathrm{~h}$ to prevent cross contamination. After $24 \mathrm{~h}$ of incubation, bags were removed and inoculated seedlings were exposed to $>90 \%$ relative humidity under misting for 6 days in a greenhouse. The experiment was conducted in a completely randomized design (CRD) with three replicates; 1 pot/replicate with 10 seedlings. Blast severity was recorded 8 days after inoculation using a 1-to- 9 progressive scale $(1=$ no lesion to small brown specks of pinhead size; 2 = larger brown specks; $3=$ small, roundish to slightly elongated, necrotic gray spots, approximately 1 to $2 \mathrm{~mm}$ in diameter, with a brown margin; 4 = typical blast lesions, elliptical, 1 to $2 \mathrm{~cm}$ long, usually confined to the area between main veins, covering $<2 \%$ of the leaf area; $5=$ typical blast lesions covering $<10 \%$ of the leaf area; $6=$ typical blast lesions covering 10 to $25 \%$ of the leaf area; $7=$ typical blast lesions covering 26 to $50 \%$ of the

Table 1. Origin, year of collection, and disease severity in the farmers' fields caused by 25 Magnaporthe grisea isolates used in the pathogenic variability study

\begin{tabular}{|c|c|c|c|c|}
\hline \multirow[b]{2}{*}{ Identity } & \multicolumn{2}{|c|}{ Origin } & \multirow[b]{2}{*}{ Year of collection } & \multirow[b]{2}{*}{ Blast severity $(\%)^{\mathrm{a}}$} \\
\hline & Cultivar & Location & & \\
\hline $\mathrm{Pg} 003$ & Great 555 & Aurangabad, Maharashtra & 2009 & 50 \\
\hline Pg007 & Pioneer 86M32 & Ahmednagar, Maharashtra & 2009 & 60 \\
\hline Pg009 & Pioneer 86M32 & Aurangabad, Maharashtra & 2009 & 50 \\
\hline $\mathrm{Pg} 021$ & Unknown hybrid & Jalna, Maharashtra & 2009 & 60 \\
\hline $\mathrm{Pg} 023$ & Paras-51 & Aurangabad, Maharashtra & 2009 & 60 \\
\hline $\mathrm{Pg} 025$ & Unknown hybrid & Dhule, Maharashtra & 2009 & 50 \\
\hline $\mathrm{Pg} 026$ & Unknown hybrid & Jalgaon, Maharashtra & 2009 & 50 \\
\hline $\mathrm{Pg} 027$ & Unknown hybrid & Jalgaon, Maharashtra & 2009 & 60 \\
\hline Pg031 & Unknown hybrid & Dhulei, Maharashtra & 2009 & 50 \\
\hline $\mathrm{Pg} 032$ & AHT-IIB & Nagpur, Maharashtra & 2009 & 50 \\
\hline $\mathrm{Pg} 037$ & Nandi 3 & Aurangabad, Maharashtra & 2009 & 50 \\
\hline Pg039 & ICMB 95222 & Hissar, Haryana & 2009 & 30 \\
\hline $\mathrm{Pg} 040$ & Unknown hybrid & Bawal, Haryana & 2009 & 40 \\
\hline Pg041 & ICMB 95444 & Jaipur, Rajastan & 2009 & 50 \\
\hline Pg043 & Unknown hybrid & Aligarh, Uttar Pradesh & 2009 & 30 \\
\hline $\mathrm{Pg} 045$ & ICMB 95444 & Patancheru, Andhra Pradesh & 2009 & 70 \\
\hline Pg049 & Supremo & Mahendergarh, Haryana & 2009 & 30 \\
\hline Pg050 & HHB 67-2 & Sundrah, Haryana & 2009 & 50 \\
\hline $\mathrm{Pg} 052$ & НHB 67 & Koka, Haryana & 2009 & 50 \\
\hline Pg053 & Pioneer 86M64 & Kherpa, Rajasthan & 2009 & 30 \\
\hline Pg055 & Proagro 9444 & Mulana, Rajasthan & 2009 & 30 \\
\hline Pg056 & Pioneer 86M52 & Gotan, Rajasthan & 2009 & 30 \\
\hline Pg057 & Unknown hybrid & Rudhia, Rajasthan & 2009 & 50 \\
\hline $\operatorname{Pg} 118$ & Unknown hybrid & Rewari, Haryana & 2010 & 60 \\
\hline $\operatorname{Pg} 119$ & Unknown hybrid & Bhojawas, Haryana & 2010 & 50 \\
\hline
\end{tabular}

${ }^{a}$ Blast severity visually assessed as percent leaf area showing typical blast symptoms in the field surveyed. 
leaf area; $8=$ typical blast lesions covering 51 to $75 \%$ of the leaf area and many leaves dead; and $9=$ all leaves dead) (22). Based on the reaction type (avirulent reaction $=$ score $\leq 3.0$ [no lesion to small necrotic spots] on a differential line and virulent reaction $=$ score $\geq 4.0$ [typical blast lesions] on 1-to-9 scale), isolates were grouped in different pathogenic groups or pathotypes. The experiment was repeated to confirm the reaction (virulent or avirulent) of isolates on host differentials.

Evaluation of pearl millet mini-core collection. Evaluation for blast resistance. The pearl millet mini-core comprising 238 accessions was evaluated under greenhouse conditions along with a susceptible (ICMB 95444) and a resistant (ICMB 06444) check against five $M$. grisea isolates (Pg118, Pg119, Pg56, Pg53, and $\mathrm{Pg} 45$ ) representing five pathotypes selected from the pathogenic variability study. Seed of the mini-core accessions was obtained from the Genetic Resources Division, ICRISAT, Patancheru, India.
The experiment was conducted in a CRD with two replicates; 1 pot/replicate with 10 seedlings, as described above.

Evaluation for agronomic traits. The mini-core was evaluated for agronomic traits such as days to $50 \%$ flowering, seed yield potential, green fodder yield potential, and overall plant aspect in an augmented design in the rainy season (June to October) in 2007 at Patancheru. Each plot consisted of a single 4-m-long row with between-row spacing of $75 \mathrm{~cm}$ and within-row spacing of $10 \mathrm{~cm}$. Data on days to $50 \%$ flowering were recorded as days from sowing to the stage when $50 \%$ of plants in an accession exhibited stigma emergence. Seed yield potential, green fodder yield potential, and overall plant aspect was visually assessed on 1-to-9 scale (9). At maturity, seed yield potential of an accession was visually assessed based on spike number, size, density, seed setting, and seed size compared with a standard check on a 1-to-9 scale $(1=$ lowest, $2=$ very low, $3=$ low, $4=$ low to moderate, $5=$ moderate, $6=\operatorname{good}, 7$

Table 2. Analysis of variance for blast reaction of host differentials to 25 isolates and mini-core accessions to five Magnaporthe grisea pathotypes ${ }^{\mathrm{a}}$

\begin{tabular}{|c|c|c|c|c|c|}
\hline Source of variation & Degree of freedom & Sum of squares & Mean square & $F$ ratio & $F$ probability \\
\hline \multicolumn{6}{|l|}{ Pathogenic variability } \\
\hline Replications & 2 & 3.6027 & 1.8013 & 11.25 & NS \\
\hline Isolate (I) & 24 & 375.232 & 15.6347 & 97.65 & $<0.001$ \\
\hline Host genotype (H) & 9 & $6,146.4587$ & 682.9399 & $4,265.66$ & $<0.001$ \\
\hline $\mathrm{I} \times \mathrm{H}$ & 216 & 626.8747 & 2.9022 & 18.13 & $<0.001$ \\
\hline Residual & 498 & 79.7307 & 0.1601 & $\ldots$ & $\ldots$ \\
\hline Total & 749 & $\ldots$ & $\ldots$ & $\ldots$ & $\ldots$ \\
\hline \multicolumn{6}{|l|}{ Mini-core screening } \\
\hline Replications & 1 & 0.4817 & 0.4817 & 4.46 & NS \\
\hline I & 4 & 866.8475 & 216.7119 & $2,006.18$ & $<0.001$ \\
\hline $\mathrm{H}$ & 239 & $2,202.993$ & 9.2175 & 85.33 & $<0.001$ \\
\hline $\mathrm{I} \times \mathrm{H}$ & 956 & $1,967.353$ & 2.0579 & 19.05 & $<0.001$ \\
\hline Residual & 1,199 & 129.5183 & 0.108 & $\ldots$ & $\ldots$ \\
\hline Total & 2,399 & $\ldots$ & $\ldots$ & $\ldots$ & $\ldots$ \\
\hline
\end{tabular}

a NS = Non-significant at $P \leq 0.05$.

Table 3. Blast severity caused by 25 isolates of Magnaporthe grisea onto 10 pearl millet genotypes in a greenhouse trial conducted at the International Crops Research Institute for the Semi-Arid Tropics, Patancheru, India during 2011

\begin{tabular}{|c|c|c|c|c|c|c|c|c|c|c|c|}
\hline \multirow[b]{2}{*}{ Isolate } & \multicolumn{11}{|c|}{ Blast severity (1-to-9 scale) ${ }^{a}$} \\
\hline & $\begin{array}{r}\text { ICMB } \\
02444\end{array}$ & $\begin{array}{r}\text { ICMB } \\
02777\end{array}$ & $\begin{array}{r}\text { ICMB } \\
06444\end{array}$ & $\begin{array}{c}\text { ICMB } \\
93333\end{array}$ & $\begin{array}{r}\text { ICMB } \\
96666\end{array}$ & $\begin{array}{c}\text { ICMB } \\
97222\end{array}$ & $\begin{array}{r}\text { ICMB } \\
99444\end{array}$ & 863B & $\begin{array}{c}\text { ICMR } \\
06222\end{array}$ & $\begin{array}{r}\text { ICMB } \\
95444\end{array}$ & Mean \\
\hline $\mathrm{Pg} 003$ & 3.0 & 8.0 & 2.0 & 1.7 & 7.7 & 1.3 & 7.7 & 1.0 & 1.0 & 8.7 & 4.2 \\
\hline Pg007 & 4.0 & 7.0 & 1.0 & 2.0 & 9.0 & 1.0 & 7.3 & 1.0 & 1.0 & 8.0 & 4.1 \\
\hline Pg010 & 4.3 & 7.3 & 2.0 & 2.0 & 8.3 & 1.3 & 8.3 & 2.0 & 2.0 & 9.0 & 4.7 \\
\hline Pg021 & 7.0 & 8.3 & 2.7 & 3.0 & 8.3 & 1.3 & 8.3 & 2.3 & 2.0 & 9.0 & 5.2 \\
\hline $\mathrm{Pg} 023$ & 4.0 & 7.3 & 2.0 & 2.0 & 7.7 & 2.0 & 7.3 & 2.0 & 3.0 & 8.7 & 4.6 \\
\hline $\mathrm{Pg} 025$ & 7.0 & 8.0 & 3.0 & 2.3 & 8.0 & 2.0 & 6.7 & 1.0 & 2.3 & 9.0 & 4.9 \\
\hline $\mathrm{Pg} 026$ & 5.0 & 8.0 & 2.0 & 2.3 & 7.7 & 2.0 & 8.0 & 2.7 & 3.0 & 9.0 & 5.0 \\
\hline $\mathrm{Pg} 027$ & 7.0 & 9.0 & 2.0 & 3.0 & 8.0 & 2.3 & 7.0 & 2.3 & 3.0 & 9.0 & 5.3 \\
\hline Pg031 & 4.0 & 7.3 & 2.0 & 2.7 & 8.7 & 1.0 & 7.7 & 1.0 & 2.0 & 8.7 & 4.5 \\
\hline $\mathrm{Pg} 032$ & 4.0 & 7.7 & 2.0 & 3.0 & 8.3 & 1.0 & 8.0 & 2.0 & 1.0 & 9.0 & 4.6 \\
\hline Pg037 & 4.0 & 7.0 & 1.0 & 2.0 & 7.7 & 1.0 & 7.3 & 1.0 & 1.7 & 9.0 & 4.2 \\
\hline $\mathrm{Pg} 039$ & 3.0 & 7.0 & 1.3 & 2.0 & 7.7 & 1.0 & 8.3 & 1.0 & 1.0 & 9.0 & 4.1 \\
\hline $\mathrm{Pg} 040$ & 3.0 & 7.7 & 2.7 & 3.0 & 8.0 & 1.0 & 8.0 & 1.7 & 1.0 & 9.0 & 4.5 \\
\hline $\mathrm{Pg} 041$ & 2.0 & 7.3 & 1.3 & 2.0 & 8.0 & 1.7 & 7.7 & 1.0 & 2.0 & 9.0 & 4.2 \\
\hline $\mathrm{Pg} 043$ & 3.0 & 7.7 & 3.0 & 2.7 & 8.0 & 3.0 & 7.0 & 1.0 & 1.0 & 9.0 & 4.5 \\
\hline $\mathrm{Pg} 045$ & 4.3 & 7.0 & 2.0 & 3.0 & 8.0 & 1.3 & 8.0 & 2.0 & 2.0 & 9.0 & 4.7 \\
\hline $\mathrm{Pg} 049$ & 2.0 & 7.3 & 1.7 & 2.0 & 8.0 & 1.0 & 7.3 & 1.3 & 2.0 & 9.0 & 4.2 \\
\hline $\mathrm{Pg} 050$ & 2.0 & 8.0 & 1.0 & 2.0 & 9.0 & 1.0 & 8.0 & 1.0 & 2.0 & 9.0 & 4.3 \\
\hline $\mathrm{Pg} 052$ & 3.0 & 7.3 & 1.0 & 2.0 & 8.3 & 1.0 & 8.3 & 1.0 & 2.0 & 9.0 & 4.3 \\
\hline $\mathrm{Pg} 053$ & 2.3 & 7.7 & 2.0 & 2.0 & 8.0 & 1.0 & 8.0 & 1.0 & 2.0 & 9.0 & 4.3 \\
\hline Pg055 & 3.0 & 7.3 & 2.0 & 2.0 & 8.0 & 1.0 & 7.0 & 1.3 & 2.0 & 9.0 & 4.3 \\
\hline Pg056 & 6.7 & 7.0 & 1.3 & 6.3 & 8.0 & 1.0 & 8.0 & 8.3 & 7.0 & 9.0 & 6.3 \\
\hline Pg057 & 3.0 & 7.3 & 2.0 & 2.0 & 8.3 & 1.0 & 8.0 & 1.0 & 1.3 & 9.0 & 4.3 \\
\hline $\operatorname{Pg} 118$ & 9.0 & 8.0 & 3.0 & 7.0 & 8.0 & 4.3 & 8.0 & 8.3 & 8.3 & 9.0 & 7.3 \\
\hline Pg119 & 4.0 & 8.0 & 1.0 & 3.0 & 8.7 & 1.3 & 7.3 & 4.3 & 3.0 & 9.0 & 5.0 \\
\hline Mean & 4.1 & 7.6 & 1.9 & 2.7 & 8.1 & 1.5 & 7.7 & 2.1 & 2.4 & 8.9 & $\ldots$ \\
\hline
\end{tabular}

${ }^{a}$ Mean of three replicates; least significant difference $(P<0.01)$ : isolate $=0.2671$; genotype $=0.169$, isolate $\times$ genotype $=0.8448$. Scale: $1=$ no lesion to small brown specks of pinhead size; $2=$ larger brown specks; $3=$ small, roundish to slightly elongated, necrotic gray spots, approximately 1 to 2 mm in diameter, with a brown margin; $4=$ typical blast lesions, elliptical, 1 to $2 \mathrm{~cm}$ long, usually confined to the area between main veins, covering $<2 \%$ of the leaf area; $5=$ typical blast lesions covering $<10 \%$ of the leaf area; $6=$ typical blast lesions covering 10 to $25 \%$ of the leaf area; $7=$ typical blast lesions covering 26 to $50 \%$ of the leaf area; $8=$ typical blast lesions covering 51 to $75 \%$ of the leaf area and many leaves dead; and $9=$ all leaves dead. 
= high, $8=$ very high, and $9=$ excellent). Green fodder yield potential was assessed based on tillering, leafiness, and bulk at flowering, and rating of overall plant aspect was based on overall agronomic desirability of accession at dough stage on 1-to-9 scale $(1=$ poorest, $2=$ very poor, $3=$ poor, $4=$ fair, $5=$ average, $6=\operatorname{good}, 7$ $=$ better, $8=$ best, and $9=$ excellent). This data set was used for agronomic comparison of selected blast-resistant mini-core accessions.

Data analysis. Analyses of variance (ANOVA) for blast scores was done using the GENSTAT statistical package (version 10.1; Rothamsted Experiment Station, Herpenden, Herts, UK) to determine significant differences among isolates and host genotypes and their interactions (14).

Disease reaction of host differentials to each isolate was used to construct a binary matrix. Avirulent reaction (score $\leq 3.0$ on a 1-to9 scale) of the isolate on the differential line was scored as 0 and virulent reaction (score $\geq 4.0$ ) as 1 . The data were then analyzed using Numerical Taxonomy System Version 2.2 (NTSYSpc). The proximity matrix was computed using the Dice similarity coefficient and a dendrogram was constructed by unweighted pair group method of arithmetic averages using the Sequential Agglomerative Hierarchal Nested cluster analysis module for the grouping of the isolates in different pathogenic groups/pathotypes (18).

\section{Results}

Pathogenic variation. Test isolates induced clear blast symptoms on the susceptible line ICMB 95444. The ANOVA revealed highly significant $(P<0.001)$ differences among isolates, host genotypes, and their interaction for blast severity (Table 2). The mean blast severity across the differentials was maximum for isolate Pg118 collected from Rewari, Haryana (score 7.3 on 1-to-9 scale) followed by Pg056 from Gotan, Rajasthan. Minimum severity was observed for $\mathrm{Pg} 007$ and $\mathrm{Pg} 039$ (score 4.1) collected from Ahmednagar, Maharashtra, and Hisar, Haryana, respectively (Table 3). Mean blast score across isolates was minimum (1.5 score) on ICMB 97222, followed by ICMB 06444 (1.9 score).

Isolates induced differential reactions on ICMB 02444, ICMB 93333, ICMB 97222, 863B, and ICMR 06222. On the basis of the reaction type (avirulent or virulent), the 25 isolates were grouped into five different pathotypes (Fig. 1). ICMB 02777, ICMB 96666 , ICMB 99444, and ICMB 95444 were highly susceptible to all 25 isolates, with a score $>7.0$. A maximum of 11 isolates was included, each in the pathogenic group or pathotype 1 and 2 , and the remaining 3 isolates represented pathotype $3(\operatorname{Pg} 119), 4(\operatorname{Pg} 056)$, and 5 (Pg118). Pathotype 5, represented by isolate Pg118 from Rewari, Haryana, was most virulent and infected all genotypes except ICMB 06444, whereas pathotype 1 was least virulent (Fig. 1). Pathotypes 1 and 2 were differentiated by their reaction (avirulent or virulent) on ICMB 02444, and 2 and 3 were differentiated by reaction on 863B. Similarly, pathotypes 3 and 4 were differentiated by reaction on ICMB 93333 and ICMR 06222, whereas 4 and 5 were differentiated by their reaction only on ICMB 97222 (Fig. 1). Among the host differentials, ICMB 06444 showed resistance (score $\leq 3.0$ ) to all 25 isolates and ICMB 97222 to 24 isolates, followed by ICMB 93333 and ICMB 06222, being resistant to 23 isolates. Host $863 \mathrm{~B}$ was resistant to 22 isolates.

Identification of blast resistance in mini-core collection. Significant variation was observed in the mini-core accessions evaluated for resistance to five isolates representing five pathotypes (Table 2). Thirty-two accessions exhibited resistance (score $\leq 3.0$ ) to at least one pathotype (Table 4). Fourteen accessions were found resistant to highly virulent pathotype 5 isolate $\mathrm{Pg} 118$. Nineteen accessions were resistant to $\mathrm{Pg} 45$ (pathotype 2) followed by six each to $\operatorname{Pg} 119$ (pathotype 3) and Pg53 (pathotype 1) and five to Pg56 (pathotype 4) (Fig. 2). In all, 78 accessions showed moderate resistance (score of 3.1 to 5.0) to $\mathrm{Pg} 118,21$ to $\mathrm{Pg} 119,43$ to $\mathrm{Pg} 56$, 69 to $\mathrm{Pg} 53$, and 15 to $\mathrm{Pg} 45$.

None of the 32 accessions selected from the mini-core were resistant to all five pathotypes; however, resistance to any four pathotypes was observed in IP 7846, IP 11036, and IP 21187 (Table 4). IP 21187 was susceptible to pathotype 2 isolate Pg45, whereas IP 7846 and IP 11036 had moderate resistance to pathotype 4 and 1, respectively. Several of these accessions had agronomic traits considered to be good. The days to $50 \%$ flowering in the 32 blast-resistant accessions ranged from 43 to 121 . Scoring for grain yield potential and overall plant aspect ranged from 4 to 7 on a 1-to- 9

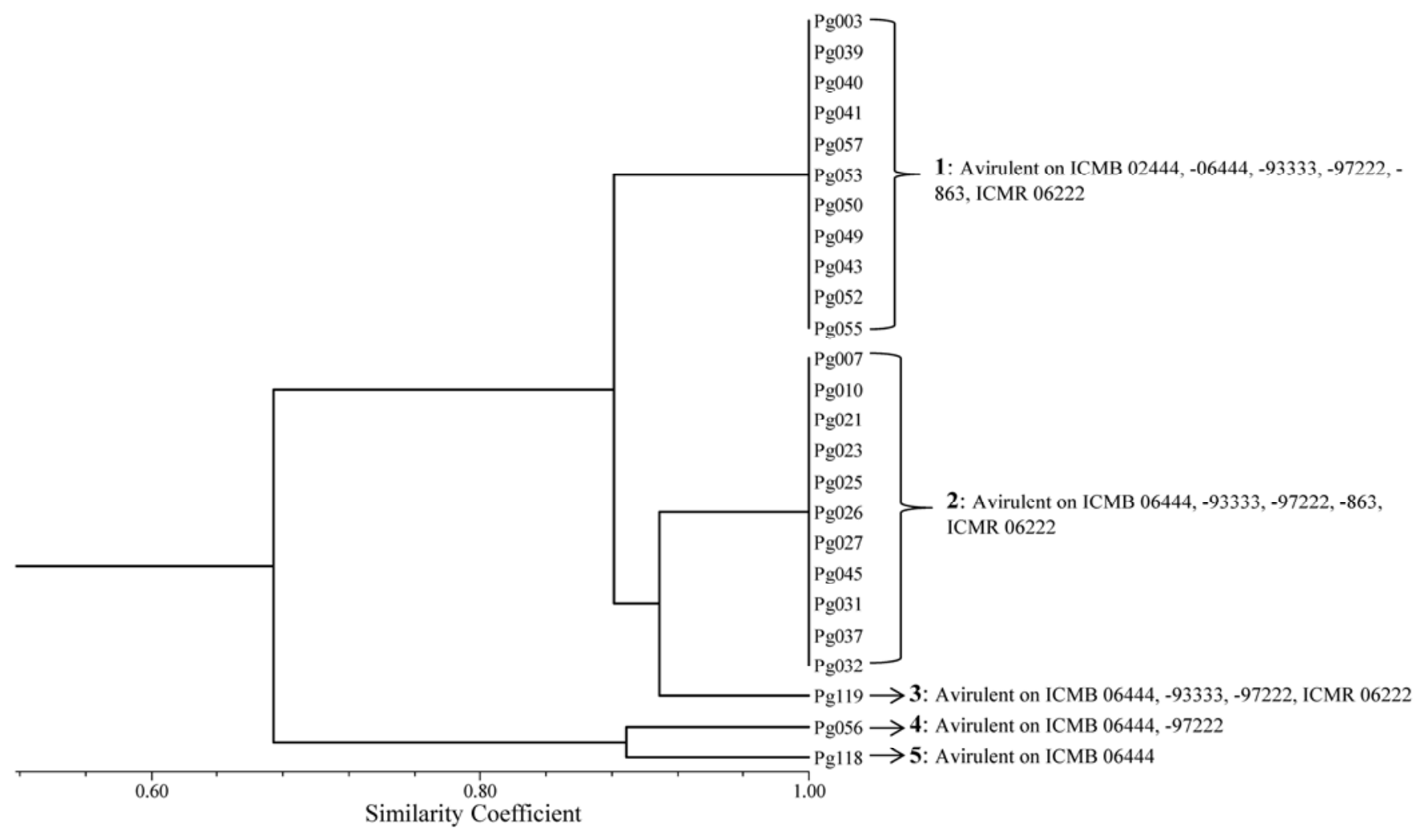

Fig. 1. Pathogenic groups of Magnaporthe grisea isolates based on reaction of 10 pearl millet genotypes. 
scale (Table 4). Similarly, the green fodder yield potential score ranged from 3 to 9 . In all, 4 of the 32 resistant accessions were early ( $\leq 50$ days), 24 medium (51 to 80 days), and 4 were late ( $>80$ days) for flowering. Four early-flowering ( $\leq 50$ days) accessions (IP 7846, IP 4291, IP 15256, and IP 22449), seven accessions (IP 4488, IP 5964, IP 8913, IP 9692, IP 11010, IP 13636, and IP 20577 ) with a high score (score 7 on a 1-to-9 scale) for grain yield potential and overall plant aspect, and four accessions (IP 8350, IP 11010, IP 14753, and IP 17396) having excellent green fodder yield potential (score 9) were found promising for utilization in pearl millet improvement. IP 5964, IP 11010, IP 13636, and IP 20577 had high scores $(\geq 7)$ for grain and green fodder yield potential and overall plant aspect.

\section{Discussion}

Pathogenic variability study of the 25 isolates of $M$. grisea collected from four major pearl millet-growing states (Rajasthan, Haryana, Maharashtra, and Uttar Pradesh) in India led to the identification of five pathogenically distinct groups or pathotypes. Many pathogenic races have been identified in $M$. grisea infecting rice, and this variability has been cited as the principal cause for the frequent breakdown of resistance in rice varieties (20). Although pathogenic variation in the $M$. grisea populations adapted to rice, wheat, foxtail millet, finger millet, and several weed hosts have been reported $(13,15,21)$, there is no information on the virulence structure of pearl millet-infecting populations of the pathogen in India. The results of our study revealed pathogenic variation in the pearl millet-infecting populations of $M$. grisea in India. Be- cause the prime objective of this study was to select pathogenically diverse isolates for greenhouse screening of pearl millet breeding lines for blast resistance, five isolates (Pg118, Pg119, Pg56, Pg53, and $\mathrm{Pg} 45$ ) representing five pathotypes have been selected and are being maintained at ICRISAT, Patancheru, India.

We could identify 32 germplasm accessions from the mini-core collection having resistance to at least one of the five pathotypes of $M$. grisea in India. Most of these accessions (21) originated in India; therefore, germplasm accessions collected from India seem to be potential sources of blast resistance and could be evaluated against different pathotypes of $M$. grisea to identify additional sources of blast resistance. Sources of blast resistance have been identified in pearl millet, and efforts have been made to incorporate resistance into improved cultivars and elite breeding lines in the United States $(7,31)$. Resistance to leaf blast in pearl millet was derived from $P$. glaucum subsp. monodii accession from Senegal (6). Blast resistance in P. glaucum subsp. monodii is controlled by three independent, dominant genes (5), although Tift 85DB, with resistance derived from $P$. glaucum subsp. monodii, was shown to have a single resistance gene (32). This resistance was effective against different isolates tested in the United States. However, Tift $85 \mathrm{DB}$ was found susceptible to the Indian isolate (4), indicating that the pearl-millet-infecting populations of $M$. grisea in India are different from those found in the United States.

Breeding for blast resistance in pearl millet is yet to begin in India. To facilitate breeding for blast resistance, information on the sources and inheritance of resistance is essential. Resistance in an elite parent line (ICMB 06222) to isolate Pg45 collected from pearl

Table 4. Origin, days to 50\% flowering (Days), seed and green fodder yield potential, overall plant aspect, and blast scores of 32 accessions selected from pearl millet mini-core collection having resistance to at least one pathotype

\begin{tabular}{|c|c|c|c|c|c|c|c|c|c|c|}
\hline \multirow[b]{2}{*}{ Acc. ${ }^{\mathrm{c}}$} & \multirow[b]{2}{*}{ Origin $^{d}$} & \multirow[b]{2}{*}{ Days } & \multicolumn{2}{|c|}{ Yield potential $^{\mathbf{a}}$} & \multirow{2}{*}{$\begin{array}{c}\text { Overall } \\
\text { plant aspect }^{\mathrm{a}}\end{array}$} & \multicolumn{5}{|c|}{ Blast score to pathotypes/isolates ${ }^{\text {b }}$} \\
\hline & & & Seed & Fodder & & 1/Pg053 & 2/Pg045 & 3/Pg119 & 4/Pg056 & 5/Pg118 \\
\hline 14753 & Cameroon & 93 & 6 & 9 & 6 & 3.0 & 7.0 & 5.5 & 3.5 & 3.0 \\
\hline 17396 & Central African Republic & 116 & 6 & 9 & 6 & 5.0 & 3.0 & 6.0 & 5.0 & 5.0 \\
\hline 21503 & France & 66 & 6 & 8 & 6 & 5.5 & 2.0 & 3.5 & 4.0 & 3.0 \\
\hline 8913 & Gambia & 67 & 7 & 6 & 7 & 7.0 & 2.0 & 5.5 & 6.5 & 4.0 \\
\hline 7846 & ICRISAT, India & 43 & 5 & 3 & 5 & 3.0 & 3.0 & 3.0 & 4.0 & 3.0 \\
\hline 12650 & ICRISAT, India & 53 & 4 & 5 & 4 & 4.0 & 7.0 & 4.5 & 5.5 & 3.0 \\
\hline 21187 & ICRISAT, India & 56 & 5 & 8 & 5 & 2.0 & 6.0 & 2.0 & 3.0 & 3.0 \\
\hline 21283 & ICRISAT, India & 60 & 6 & 5 & 6 & 7.0 & 2.0 & 7.0 & 7.0 & 7.0 \\
\hline 22449 & ICRISAT, India & 47 & 4 & 4 & 4 & 5.0 & 2.0 & 3.0 & 6.0 & 3.5 \\
\hline 3110 & India & 76 & 6 & 8 & 6 & 5.0 & 8.0 & 6.0 & 7.0 & 3.0 \\
\hline 3329 & India & 56 & 5 & 7 & 5 & 3.0 & 7.5 & 5.5 & 7.5 & 5.5 \\
\hline 3646 & India & 54 & 5 & 6 & 5 & 6.0 & 2.0 & 6.0 & 5.0 & 5.0 \\
\hline 3706 & India & 53 & 6 & 5 & 6 & 4.0 & 2.0 & 3.5 & 4.5 & 4.0 \\
\hline 4291 & India & 46 & 5 & 7 & 5 & 5.0 & 3.0 & 6.0 & 6.0 & 5.5 \\
\hline 4488 & India & 56 & 7 & 6 & 7 & 4.0 & 2.0 & 3.0 & 4.0 & 5.0 \\
\hline 7259 & India & 65 & 5 & 7 & 5 & 4.0 & 3.0 & 6.0 & 7.0 & 6.0 \\
\hline 7358 & India & 74 & 6 & 7 & 5 & 6.0 & 3.0 & 5.0 & 4.0 & 4.0 \\
\hline 8350 & India & 65 & 6 & 9 & 6 & 6.0 & 6.0 & 6.0 & 6.0 & 3.0 \\
\hline 9198 & India & 52 & 5 & 5 & 5 & 4.0 & 5.0 & 4.5 & 4.0 & 3.0 \\
\hline 11010 & India & 76 & 7 & 9 & 7 & 5.0 & 6.0 & 2.0 & 4.0 & 2.0 \\
\hline 11036 & India & 52 & 6 & 7 & 6 & 4.0 & 3.0 & 3.0 & 3.0 & 3.0 \\
\hline 11044 & India & 54 & 6 & 6 & 6 & 6.0 & 3.0 & 6.0 & 6.0 & 5.0 \\
\hline 13636 & India & 57 & 7 & 8 & 7 & 4.0 & 3.0 & 5.0 & 5.0 & 5.0 \\
\hline 15095 & India & 72 & 6 & 7 & 6 & 7.0 & 3.0 & 7.0 & 5.0 & 3.0 \\
\hline 15256 & India & 50 & 5 & 6 & 5 & 3.0 & 5.5 & 4.0 & 3.0 & 3.0 \\
\hline 7915 & Niger & 74 & 5 & 7 & 5 & 7.0 & 2.0 & 6.0 & 3.0 & 5.0 \\
\hline 9692 & Nigeria & 60 & 7 & 6 & 7 & 5.0 & 3.0 & 6.0 & 6.0 & 4.0 \\
\hline 20577 & Nigeria & 121 & 7 & 7 & 7 & 3.0 & 8.0 & 7.5 & 6.0 & 5.5 \\
\hline 5964 & Senegal & 94 & 7 & 8 & 7 & 4.0 & 2.0 & 6.0 & 5.0 & 3.5 \\
\hline 13261 & Senegal & 67 & 6 & 8 & 6 & 5.0 & 6.0 & 7.0 & 3.0 & 5.5 \\
\hline 2083 & South Africa & 55 & 7 & 7 & 6 & 6.0 & 4.0 & 6.5 & 6.0 & 3.0 \\
\hline 11247 & Zimbabwe & 59 & 6 & 6 & 6 & 6.0 & 8.0 & 6.0 & 5.0 & 2.0 \\
\hline Trial mean & $\ldots$ & 65.7 & $\ldots$ & $\ldots$ & $\ldots$ & 5.8 & 7.3 & 6.3 & 6.1 & 5.56 \\
\hline CV (\%) & $\ldots$ & 6.5 & $\ldots$ & $\ldots$ & $\ldots$ & 4.9 & 3.6 & 6.9 & 5.7 & 5.0 \\
\hline LSD & $\ldots$ & 8.5 & $\cdots$ & $\ldots$ & $\ldots$ & 0.56 & 0.52 & 0.85 & 0.68 & 0.55 \\
\hline
\end{tabular}

\footnotetext{
${ }^{\text {a }}$ Scored on a 1 -to- 9 scale, where $1=$ poorest, $2=$ very poor, $3=$ poor, $4=$ fair, $5=$ average, $6=$ good, $7=$ better, $8=$ best, and $9=$ excellent.

${ }^{\mathrm{b}}$ Mean of two replicates: resistant $=$ score $\leq 3.0$; moderately resistant $=$ score 3.1 to 5.0 ; susceptible $=$ score 5.1 to 7.0 ; and highly susceptible $=$ score $>7.0$.

${ }^{c}$ Accession (IP) number; $\mathrm{CV}=$ coefficient of variation; and LSD = least significant difference.

${ }^{\mathrm{d}}$ ICRISAT $=$ International Crops Research Institute for the Semi-Arid Tropics.
} 


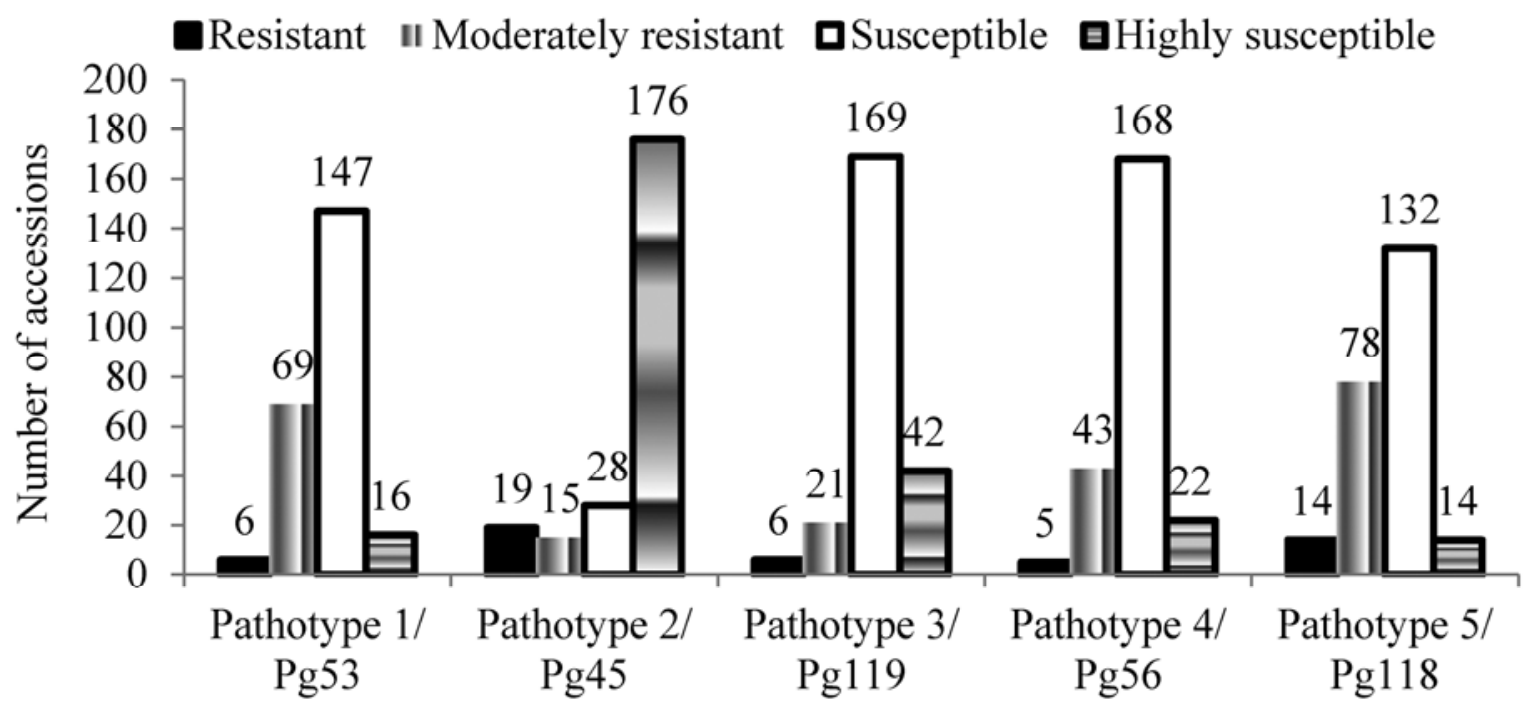

Fig. 2. Number of accessions ( $n=238$ ) expressing resistant to highly susceptible reaction against five Magnaporthe grisea pathotypes.

millet fields at ICRISAT, Patancheru, India was found to be governed by a single dominant gene (4). Because the chances of breaking down major genes are more because of race specificity and the rapid change in pathogenicity in the blast fungus (19), it would be prudent to collect diverse sources of resistance and deploy them in pearl millet hybrid parent lines to prevent disease outbreaks. Of the 32 accessions selected from the mini-core, 3 (IP 7846, IP 11036, and IP 21187) were resistant to any four pathotypes: IP 11036 and IP 7846 also exhibited moderate resistance to the fifth pathotype. IP 7846 is an early maturing line, with $<45$ days to $50 \%$ flowering, and, thus, could be a potential source for breeding early maturing, high-yielding, blast-resistant pearl millet lines and hybrids. The 32 blast-resistant accessions in the mini-core were selected from 26 of the 136 clusters of the core collection. Interestingly, all three accessions included in the mini-core from cluster number 25 (IP 21503, IP 22449, and IP 15256) were resistant to two to three pathotypes and also had moderate resistance to one to two pathotypes. Similarly, two accessions (IP 4488 and IP 11036) out of three in the mini-core collection selected from cluster 36 exhibited multiple pathotype resistance. The cluster to which a particular accession with a trait of interest belongs provides important direction for further focused large-scale screening efforts, because the success rate of identifying additional resistant lines from these clusters has been found to be quite high $(P \leq 0.01)(8)$. Therefore, it would be useful to evaluate the remaining 23 accessions each from clusters 25 and 36 for additional sources of multiple pathotype resistance. Two hybrid parent lines (ICMB 06444 and ICMB 97222) used as host differentials in this study also exhibited high levels of blast resistance. Therefore, resistance to multiple pathotypes identified in the mini-core accessions as well as in the elite parental lines ICMB 06444 and ICMB 97222 can be exploited for the development of high-yielding, blast-resistant pearl millet hybrids in India.

\section{Acknowledgments}

We thank the Bill \& Melinda Gates Foundation project on "Harnessing Opportunities for Productivity Enhancement (HOPE) of Sorghum and Millets in Sub-Saharan Africa and South Asia" and the Pearl Millet Hybrid Parental Research Consortium for partial funding support to carry out this research work.

\section{Literature Cited}

1. Anonymous 2011. Annual Report. All India Coordinated Pearl Millet Improvement Project, Indian Council of Agricultural Research, Mandore, Jodhpur.

2. Bhattacharjee, R., Khairwal, I. S., Bramel, P. J., and Reddy, K. N. 2007. Establishment of a pearl millet (Pennisetum glaucum (L.) R. Br.) core collection based on geographical distribution and quantitative traits. Euphytica 155:35-45.

3. Frankel, O. H., and Brown, A. H. D. 1984. Plant genetic resources today: a critical appraisal. Pages 249-268 in: Crop Genetic Resources: Conservation and Evaluation. J. H. W. Holden and J. T. Williams, eds. Allen and Unwin, Winchester, MA.

4. Gupta, S. K., Sharma, R., Rai, K. N., and Thakur, R. P. 2012. Inheritance of foliar blast resistance in pearl millet (Pennisetum glaucum L. (R.) Br.). Plant Breed. 131:217-219.

5. Hanna, W. W., and Wells, H. D. 1989. Inheritance of Pyricularia leaf spot resistance in pearl millet. J. Hered. 80:145-147.

6. Hanna, W. W., Wells, H. D., and Burton, G. W. 1987. Registration of pearl millet inbred parental lines, Tift $85 \mathrm{D}_{2} \mathrm{~A}_{1}$ and Tift $85 \mathrm{D}_{2} \mathrm{~B}$. Crop Sci. 27:1324-1325.

7. Hanna, W. W., Wells, H. D., Burton, G. W., and Monson, W. G. 1988. Registration of 'Tifleaf 2' pearl millet. Crop Sci. 28:1023.

8. Holbrook, C. C., and Anderson, W. F. 1995. Evaluation of a core collection to identify resistance to late leaf spot in peanut. Crop Sci. 35:1700-1702.

9. IBPGR, and ICRISAT. 1993. Descriptors for Pearl Millet (Pennisetum glaucum (L.) R. Br.). Int. Board for Plant Genetic Resources, Rome; and Int. Crops Res. Inst. for the Semi-Arid Tropics, Patancheru, Andhra Pradesh, India.

10. Kang, S., and Lee, Y. H. 2000. Population structure and race variation of the rice blast fungus. Plant Pathol. J. 16:1-8.

11. Lukose, C. M., Kadvani, D. L., and Dangaria, C. J. 2007. Efficacy of fungicides in controlling blast disease of pearl millet. Indian Phytopathol. 60:6871.

12. Mehta, P. R., Singh, B., and Mathur, S. C. 1953. A new leaf spot disease of bajra (Pennisetum typhoides Staph and Hubbard) caused by a species of Pyricularia. Indian Phytopathol. 5:140-143.

13. Nakayama H, Nagamine T and Hayashi N. 2005. Genetic variation of blast resistance in foxtail millet (Setaria italica (L.) P. Beauv.) and its geographic distribution. Genet. Resour. Crop Evol. 52:863-868.

14. Payne, R. W. 2002. The Guide to GenStat (R) Release 6.1. Part 2: Statistics. VSN International Ltd., Oxford.

15. Prabhu, A. S., Filippi, M. C., and Castro, N. 1992. Pathogenic variation among isolates of Pyricularia grisea infecting rice, wheat, and grasses in Brazil. Trop. Pest Manage. 38:367-371.

16. Rai, K. N., Khairwal, I. S., Dangaria, C. J., Singh, A. K., and Rao, A. S. 2009. Seed parent breeding efficiency of three diverse cytoplasmic-nuclear male-sterility systems in pearl millet. Euphytica 165:495-507.

17. Rai, K. N., Kulkarni, V. N., Thakur, R. P., Haussmann, B. I. G., and Mgonja, M. A. 2006. Pearl millet hybrid parents research: approaches and achievements. Pages 11-73 in: Hybrid Parents Research at ICRISAT. C. L. L. Gowda, K. N. Rai, B. V. S. Reddy, and K. B. Saxena, eds. International Crops Research Institute for the Semi-Arid Tropics, Patancheru 502 324, Andhra Pradesh, India.

18. Rohlf, F. J. 2000. NTSYS-pc: Numerical Taxonomy and Multivariate Analysis System, Version 2.2. Exeter Software. Setauket, NY.

19. Srinivasachary, Hittalmani, S., Shivayogi, S., Vaishali, M. G., Shashidhar, H. E., and Kumar, G. K. 2002. Genetic analysis of rice blast fungus of southern Karnataka using DNA markers and reaction of popular rice genotypes. Curr. Sci. 82:732-735.

20. Suh, J. P., Roh, J. H., Cho, Y. C., Han, S. S., Kim, Y. G., and Jena, K. K. 2009. The Pi40 gene for durable resistance to rice blast and molecular analysis of Pi40-advanced backcross breeding lines. Phytopathology 99:243-250.

21. Takan, J. P., Chipili, J., Muthumeenakshi, S., Talbot, N. J., Manyasa, E. O., Bandyopadhyay, R., Sere, Y., Nutsugah, S. K., Talhinhas, P., Hossain, M., Brown, A. E., and Sreenivasaprasad, S. 2012. Magnaporthe oryzae populations adapted to finger millet and rice exhibit distinctive patterns 
of genetic diversity, sexuality and host interaction. Mol. Biotechnol. 50:145-158.

22. Thakur, R. P., Sharma, R., Rai, K. N., Gupta, S. K., and Rao, V. P. 2009. Screening techniques and resistance sources for foliar blast in pearl millet. J. SAT Agric. Res. 7:1-5.

23. Timper, P, Wilson, J. P., Johnson, A. W., and Hanna, W. W. 2002. Evaluation of pearl millet grain hybrids for resistance to Meloidogyne spp. and leaf blight caused by Pyricularia grisea. Plant Dis. 86:909-914.

24. Upadhyaya, H. D., Gowda, C. L. L., Reddy, K. N., and Singh, S. 2009. Augmenting the pearl millet core collection for enhancing germplasm utilization in crop improvement. Crop Sci. 49:573-580.

25. Upadhyaya, H. D., and Ortiz, R. 2001. A mini-core collection for capturing diversity and promoting utilization of chickpea genetic resources in crop improvement. Theor. Appl. Genet. 102:1292-1298.

26. Upadhyaya, H. D., Pundir, R. P. S., Gowda, C. L. L., Reddy, V. G., and Singh, S. 2008. Establishing a core collection of foxtail millet to enhance utilization of germplasm of an underutilized crop. Plant Genet. Resour. Online publication. doi:10.1017/S1479262108178042
27. Upadhyaya, H. D., Reddy, K. N., and Gowda, C. L. L. 2007. Pearl millet germplasm at ICRISAT genebank-status and impact. J. SAT Agric. Res. 3:1-5.

28. Upadhyaya, H. D., Yadav, D., Reddy, K. N., Gowda, C. L. L., and Singh, S. 2011. Development of pearl millet minicore collection for enhanced utilization of germplasm. Crop Sci. 51:217-223.

29. Wilson, J. P., Burton, G. W., Wells, H. D., Zongo, J. D., and Dicko, I. O. 1989. Leaf spot, rust and smut resistance in pearl millet landraces from central Burkina Faso. Plant Dis. 73:345-349.

30. Wilson, J. P., and Gates, R. N. 1993. Forage Yield losses in hybrid pearl millet due to leaf blight caused primarily by Pyricularia grisea. Phytopathology 83:739-743.

31. Wilson, J. P., and Hanna, W. W. 1992. Effects of gene and cytoplasm substitutions in pearl millet on leaf blight epidemics and infection by Pyricularia grisea. Phytopathology 82:839-842.

32. Wilson, J. P., Wells, H. D., and Burton, G. W. 1989. Inheritance of resistance to Pyricularia grisea in pearl millet accessions from Burkina Faso and inbred Tift 85DB. J. Hered. 80:499-501. 